\title{
The effect of complex herbal extract and methotrexate on suppressing adjuvant arthritis in rats
}

\author{
Rūta Bradūnaitè ${ }^{1 *}$, Laima Leonavičienè ${ }^{1}$, Laimis Akramas ${ }^{2}$, Audrius Vasiliauskas', \\ Irena Dumalakiené $\dot{e}^{3}$, Rita Viliené $\dot{e}^{3}$, Irena Jonauskiené ${ }^{1}$, Zygmunt Mackiewicz ${ }^{4}$, \\ and Miglẻ Leonavičiūtẻ - Klimantavičiené ${ }^{5}$ \\ ${ }^{1}$ Department of Biomodels, State Research Institute Centre for Innovative Medicine, Vilnius, Lithuania \\ ${ }^{2}$ Pharmaceutical Company "Aksada", Kaunas, Lithuania \\ ${ }^{3}$ Immunology Department, State Research Institute Centre for Innovative Medicine, Vilnius, Lithuania \\ ${ }^{4}$ Department of Regenerative Medicine, State Research Institute Centre for Innovative Medicine, Vilnius, Lithuania \\ ${ }^{5}$ Vilnius University Faculty of Medicine, Vilnius, Lithuania
}

BRADŪNAITE், R., L. LEONAVIČIENĖ, L. AKRAMAS, A. VASILIAUSKAS, I. DUMALAKIENE், R. VILIENĖ, I. JONAUSKIENĖ, Z. MACKIEWICZ, M. LEONAVIČIŪTE் - KLIMANTAVIČIENĖ: The effect of complex herbal extract and methotrexate on suppressing adjuvant arthritis in rats. Vet. arhiv 91, 411425, 2021.

\section{ABSTRACT}

The present study evaluated the therapeutic benefits of complex herbal preparation named CBMDS, consisting of turmeric (Curcuma longa), Boswellia (Boswellia serrata), Methylsulphonylmethane, Devil's Claw (Harpagophytum procumbens) and Silymarin, using it in combination with methotrexate, in order to suppress adjuvant arthritis in rats, and to attenuate methotrexate-induced liver damage. Adjuvant arthritis was induced in 28 rats by a single subplantar injection of complete Freund's adjuvant $(0.1 \mathrm{~mL})$ into the left hind paw. The animals were divided into four groups (with seven animals in each). Group I received CBMDS, Group II - CBMDS in combination with methotrexate, and Group III just methotrexate. The treatment lasted from day 0 to day 17 (CBMDS was given daily except weekends in a dose of $160 \mathrm{mg} / \mathrm{kg}$, methotrexate - $2 \mathrm{mg} / \mathrm{kg}$ once a week). Group IV was the control group. Clinical (body weight, hind paw volume, erythrocyte sedimentation rate, leukocyte count), biochemical (serum pro-/antioxidant activity markers), immunological (serum interleukin levels) and histological changes in joint and liver tissues were evaluated. CBMDS significantly alleviated arthritis and reduced hepatic damage, which was more evident in the methotrexate group. The combined treatment also markedly reduced arthritic symptoms and levels of malondialdehyde. Antioxidant activity was significantly higher in treated Groups I and II. CBMDS and its combination with methotrexate promoted antiarthritic action, reduced histological changes in the joint tissues, and minimized methotrexate-induced liver toxicity.

Key words: adjuvant arthritis; complex of herbal extracts; methotrexate; antioxidant activity

\footnotetext{
*Corresponding author:

Dr. Rūta Bradūnaite, Department of Biomodels, State Research Institute Centre for Innovative Medicine, Santariškių str. 5, LT-08406 Vilnius, Lithuania, E-mail: ruta.bradunaite@imcentras.lt
} 
R. Bradūnaite et al.: Complex natural substances ameliorate methotrexate effects in treatment of rat adjuvant arthritis

\section{Introduction}

Rheumatoid arthritis (RA) is a chronic systemic autoimmune disease, characterized by inflammation of joints, destruction of articular tissues, and deformation of fingers and palms. This disease requires sustained treatment, so medications used in management of RA should be well tolerated. Methotrexate (MTX), an antiproliferative and immunosuppressive agent, is the disease modifying anti-rheumatic drug (DMARD) used for the treatment of RA (FRIEDMAN and CRONSTEIN, 2019; GREMESE et al., 2019). It is a folic acid antagonist, used alone or in combination with other therapeutic agents. However, despite the efficacy of MTX in reducing inflammation, its benefits are impaired by its toxicity resulting in poor compliance (BANJI et al., 2011; FRIEDMAN and CRONSTEIN, 2019). Due to adverse effects, combined therapy of MTX with a number of natural substances is being explored to eliminate or minimize MTX toxicity (ISMAIL et al., 2018; ZUO et al., 2018; HE et al., 2019).

Among these substances, curcumin, derived from the root of Curcuma longa (turmeric), which is rich in diferuloylmethane, has been investigated as one of the most promising natural active ingredients (TATY ANNA et al., 2011; MESHKIBAF et al., 2019) for its anti-inflammatory (SHEHZAD et al., 2013) and antioxidant effects (MESHKIBAF et al., 2019).

Boswellic extract (BSE) is used for the treatment of chronic inflammatory diseases (AMMON et al., 2016; MAJEED et al., 2019). Due to its antiinflammatory effect, BSE can be used as an antiarthritic drug (KUMAR et al., 2019).

Methylsulphonylmethane (MSM) has been widely used as a dietary supplement for its beneficial effects against various diseases, especially arthritis, in order to reduce arthritic and rheumatic pain (DEBBI et al., 2011; EZAKI et al., 2013; BUTAWAN et al., 2017) and (often in combination with other supplements, such as glucosamine and chondroitin) to treat or prevent osteoarthritis (LUBIS et al., 2017). It also used in sport horses following jumping exercise, to reduce oxidative stress (MARAÑÓN et al., 2008).

Devil's Claw is widely recommended as a popular anti-inflammatory and analgesic agent for the treatment of musculoskeletal disorders
(ANDERSEN et al., 2004; ZHANG et al., 2011), and the antioxidant properties of Devil's Claw extract have been highlighted in experimental studies (SCHAFFER et al., 2013; GRABS et al., 2014). It has been used for the treatment of inflammatory symptoms and degenerative disorders in horses for many years (AXMAN et al., 2018).

The complex of flavonoids (silibinin, silydianin, silychristin and others) known as silymarin is a biologically active preparation (WIANOWSKA and WIŚNIEWSKI, 2015). It exhibits anti-inflammatory, antioxidant, anti-apoptotic, and immunosuppressive properties (SHAVANDI et al., 2017; DUPUIS et al., 2018; KANDEMIR et al., 2017). Silymarin has the potential to alleviate the adverse effects of oxidative stress on poultry farms (BARADARAN et al., 2019), and shows hepatoprotective effects on $\mathrm{CCl}_{4}$ induced hepatic damage in a broiler chicken model, and on acetaminophen-induced hepatotoxicity in mice (BARADARAN et al., 2019; ELSAYED ELGARAWANY et al., 2019).

Numerous plant extracts, including curcumin, Boswellia extract, and MSM, have shown effect, by reducing pain and functional disability, stronger than that observed with analgesics and glucosamine/chondroitin products (HENROTIN and MOBASHERI, 2018). Devil's claw extract ( $3 \%$ harpagoside), in addition to bromelain extract, glucosamine hydrochloride, chondroitin sulfate and MSM, is able to prevent cartilage destruction, and decrease oxidative stress, by reducing malondialdehyde (MDA), and inflammation (UCUNCU et al., 2015).

Our experiments of recent years have revealed that some substances derived from herbs also show an anti-arthritic effect using an adjuvant arthritis model (AKRAMAS et al., 2017; AKRAMAS et al., 2019).

In this study, we explored the anti-arthritic effect of a preparation named CBMDS, alone or in combination with MTX, by using adjuvant arthritis (AA) as the experimental model of RA, which is extensively used for testing natural (AKRAMAS et al., 2019) or therapeutic (BRADŪNAITÉ et al., 2001) products. We also evaluated the potential properties of CBMDS to reduce hepatotoxicity of MTX when both preparations are used in combination. 


\section{Materials and methods}

Preparations and chemicals. Complete Freund's adjuvant (CFA - Sigma Aldrich, USA), acetic acid, trichloracetic acid, orthophosphoric acid, thiobarbituric acid, nitric acid, ascorbic acid, ferrous sulphate, ammonium molybdate, hydrogen peroxide, $10 \%$ neutral buffered formalin, hematoxylin, eosin, toluidine blue, was obtained from Sigma-Aldrich Chemie and Fluka Chemie $\mathrm{GmbH}$ (Germany), ketamidor - from Richter Pharma AG (Wels, Austria) and sedaxylan - from Eurovet Animal Health B.V (Holland); tetrachloroauric acid $\left(\mathrm{HAuCl}_{4} \cdot 3 \mathrm{H}_{2} \mathrm{O}\right)$ and tannic acid - from Carl Roth GmbH\&Co (Germany), sodium citrate - from Penta (Czech Republic), MTX - from Ebewe (Austria). The Commercial ELISA abcam ${ }^{\circledR}$ Kit for IL-17 and Thermo Scientific Rat IL-1 $\beta$ ELISA Kit for IL- $1 \beta$ were used for detection of IL-levels in blood serum. The preparation with the code name CBMDS consisting of turmeric dry extract (curcuminoids 98\%), Boswellia dry extract (boswellic acid 30\%), MSM, Devil's Claw extract and Silymarin used in experiment was prepared by the Pharmaceutical company "Aksada" (Kaunas, Lithuania), and provided for investigation in rats with experimental AA.

Animals. Twenty-eight male albino Wistar rats weighing 180-230 g, were obtained from the breeding center of the State Research Institute, Centre for Innovative Medicine, Department of Biomodels (Vilnius, Lithuania), and used for the study. The animals were housed in suitable cages and acclimatized to laboratory conditions for a period of one week before the commencement of the experiment. The rats were fed with standard rodent food pellets (JCS; Litagra Company Group, Lithuania), and received water ad libitum. All animals were humanely treated, in accordance with the Directive 2010/63/EU of the European Parliament and the Council of 22 September 2010 on the protection of animals used for scientific purposes. The study design was approved by the Lithuanian Laboratory Animal Use Ethics Committee, under the State Food and Veterinary Service (Protocol No. G2-31).

Induction of arthritis and treatment schedule. Arthritis was induced by subplantar injection of $0.1 \mathrm{~mL}$ CFA into the left hind paw of anaesthetized animals (ketamidor and sedaxylan - $0.1 \mathrm{~mL}$ i.m.). The animals were divided into four groups (with seven animals in each). Group I received CBMDS, Group II - CBMDS in combination with MTX, and Group III - MTX alone. Group IV was the arthritis control group. The treatment lasted from day 0 to day 17 (CBMDS was given daily, except weekends in a dose of $160 \mathrm{mg} / \mathrm{kg}$, MTX - $2 \mathrm{mg} / \mathrm{kg}$, once a week). Preparations were suspended in $1 \%$ starch gel and injected orally by gastric intubation at a volume of $1 \mathrm{~mL}$ per rat. The control group received the same volume orally of starch gel as the vehicle on the treatment days.

Measurements. Arthritis development was evaluated clinically and histologically. Body weight and joint swelling were evaluated 7 times during the whole experiment, which lasted for 17 days. Paw volumes were measured using a Plethysmometer PVP1001 (Kent Scientific Corporation, USA).

At the end of experiment (on day 18) the animals were humanely sacrificed by decapitation under ketamidor and sedaxylan anesthesia $(0.1 \mathrm{~mL}$ i.m.). The general condition of the animals, their weight, macroscopic changes to internal organs, and indices of inflammatory processes were evaluated. Erythrocyte sedimentation rate (ESR) and leukocyte count were estimated using a Picoscale hematological analyzer (Hungary). Blood samples were collected in graded tubes during decapitation, and centrifuged at $800 \mathrm{x} g$ for $10 \mathrm{~min}$. to obtain serum samples, which were stored frozen at $-20{ }^{\circ} \mathrm{C}$ until testing. The concentration of MDA, catalase (CAT) activity and the total antioxidant activity (AOA) in the blood serum were investigated according to the methods described by GAVRILOV et al. (1987), KOROLIUK et al. (1988) and GALAKTIONOVA et al. (1998). A precise description of these methods has been published previously (AKRAMAS et al., 2015).

Estimation of $I L-17$ and $I L-1 \beta$ in blood serum. Cytokine IL-17 levels in the blood serum of the control and test animals were measured by an enzyme-linked immunosorbent assay (ELISA) kit specific for rats (ab119536-IL-17 Rat ELISA Kit) according to the procedure recommended by the manufacturer's instructions $\left(a^{\circ} c a m^{\circledR}, U K\right)$. IL-1 $\beta$ levels in blood serum were measured using a Thermo Scientific Rat IL-1 $\beta$ ELISA Kit. Each sample was assayed in duplicate.

Histology. The livers and damaged joints of the rats were taken, fixed in formalin, decalcified, 
R. Bradūnaite et al.: Complex natural substances ameliorate methotrexate effects in treatment of rat adjuvant arthritis

and embedded in paraffin. Deparaffinized $5 \mu \mathrm{m}$ histological sections of joints and liver were stained with hematoxylin-eosin (H\&E) and toluidine blue for histopathological examination with a light microscope. All histological material was evaluated by a blind method by two independent pathologists. Each parameter was scored on a 0 to 3 point scale, where 0 means the absence of changes, 0.5 - traces of changes, 1 - minimal changes, 2 - moderate changes, 3 - severe changes.

\section{Results}

Clinical and hematological indices. Although an increase in animal body weight was observed in all treated groups during the experiment, no significant differences were found between the test and the control AA groups (data not shown). Only on the last day of the study was a marked increase in body weight noticed in animals that received CBMDS $(257.43 \pm 9.22 \mathrm{~g}$ - test group; $223.12 \pm 11.71 \mathrm{~g}$ - the control AA group; $\mathrm{P}<0.05$ ).

Visual changes were not observed in the macroscopic examination of the internal organs. The relative weight of kidneys was significantly lower $(\mathrm{P}<0.05)$ in Groups II and III in comparison with Group IV (control). The spleen weight was markedly lower in all treated groups (Table 1): in Groups I and II spleen weight decreased by $21 \%$ ( $\mathrm{P}<0.01$ and $\mathrm{P}<0.02$ respectively), and in the Group III - by $34.2 \%(\mathrm{P}<0.001)$ showing the positive effect of the preparations. The thymus was found to have a significantly lower relative weight $(\mathrm{P}<0.001)$ after the treatment with CBMDS.
Statistics. ANOVA statistical analysis was performed using PRISM Software (GraphPad Software, San Diego, CA, USA) and the differences between the groups were determined by Student's $t$ test. The nonparametric Mann-Whitney U test was used to evaluate the histological changes. All data were expressed as the mean value \pm SEM and were considered to be statistically significant at $\mathrm{P}<0.05$.

During the study, significant suppression of joint swelling was observed in all treated groups (Fig. 1). The suppressing effect of the investigated compounds on the joints was similar, and exceeded by more than $50 \%$ the control group at the end of experiment: $57.9 \%(\mathrm{P}<0.0001), 51.5 \%(\mathrm{P}<0.0001)$, and $54.5 \% \quad(\mathrm{P}<0.0001)$ in groups receiving CBMDS, its combination with MTX, and MTX alone, respectively.

The analysis of blood parameters at the end of experiment (Fig. 2) showed a statistically significant decrease in ESR in groups treated with CBMDS $(\mathrm{P}<0.0001)$, its combination with MTX $(\mathrm{P}<0.0001)$ and MTX alone $(\mathrm{P}<0.001)$ in comparison with the control AA group. All investigated compounds also significantly diminished the leukocyte count: CBMDS - by 48.6\% (P<0.001), CBMDS+MTX by $48 \%(\mathrm{P}<0.001)$, MTX - by $39.2 \%(\mathrm{P}<0.002)$.

Changes in pro-inflammatory cytokines IL17 and $I L-1 \beta$ in blood serum. Treatment with the preparation CBMDS, its combination with MTX and

Table 1. Body and relative organ weight in rats with adjuvant arthritis treated with CBMDS preparation, its combination with MTX and MTX alone

\begin{tabular}{|c|c|c|c|c|c|}
\hline Groups & Body weight $(\mathrm{g})$ & $\begin{array}{c}\text { Liver } \\
\left(\mathrm{g} / \mathrm{kg}^{-1}\right)\end{array}$ & $\begin{array}{c}\text { Kidneys } \\
\left(\mathrm{g} / \mathrm{kg}^{-1}\right)\end{array}$ & $\begin{array}{c}\text { Spleen } \\
\left(\mathrm{g} / \mathrm{kg}^{-1}\right)\end{array}$ & $\begin{array}{c}\text { Thymus } \\
\left(\mathrm{g} / \mathrm{kg}^{-1}\right)\end{array}$ \\
\hline I CBMDS & $257.43 \pm 9.22 *$ & $3.45 \pm 0.10$ & $0.82 \pm 0.02$ & $0.30 \pm 0.01 *$ & $0.14 \pm 0.01 *$ \\
\hline II CBMDS+MTX & $242.29 \pm 11.02$ & $3.30 \pm 0.14$ & $0.79 \pm 0.01 *$ & $0.30 \pm 0.02 *$ & $0.21 \pm 0.02$ \\
\hline III MTX & $243.86 \pm 8.85$ & $3.45 \pm 0.13$ & $0.80 \pm 0.01 *$ & $0.25 \pm 0.01 *$ & $0.24 \pm 0.01$ \\
\hline IV Control & $223.12 \pm 11.71$ & $3.42 \pm 0.15$ & $0.89 \pm 0.04$ & $0.38 \pm 0.02$ & $0.24 \pm 0.02$ \\
\hline
\end{tabular}

Adjuvant arthritis (AA) was induced by injection $0.1 \mathrm{~mL}$ of complete Freund's adjuvant (CFA) into the left hind paw. The test groups with AA were treated from AA induction day: Group I with CBMDS preparation, Group II - with a combination of CBMDS and methotrexate (MTX), Group III - with MTX. Group IV - AA control without treatment. * The differences are significant in comparison with the control AA group. 
R. Bradūnaitè et al.: Complex natural substances ameliorate methotrexate effects in treatment of rat adjuvant arthritis

Table 2. Pathomorphological changes in the liver of rats with adjuvant arthritis treated with CBMDS preparation, its combination with MTX and MTX alone

\begin{tabular}{|l|l|c|c|c|c|}
\hline \multirow{2}{*}{\multicolumn{2}{|c|}{ Index }} & \multicolumn{4}{c|}{ Groups } \\
\cline { 2 - 6 } & $\begin{array}{c}\text { I } \\
\text { CBMDS }\end{array}$ & $\begin{array}{c}\text { II } \\
\text { CBMDS+MTX }\end{array}$ & $\begin{array}{c}\text { III } \\
\text { MTX }\end{array}$ & $\begin{array}{c}\text { IV } \\
\text { AA control }\end{array}$ \\
\hline \multicolumn{2}{|c|}{ Alterations of parenchyma } & $0.57 \pm 0.07$ & $0.21 \pm 0.10 *$ & $0.86 \pm 0.14$ & $0.64 \pm 0.09$ \\
\hline \multicolumn{2}{|l|}{ V. centralis hypervolemia } & $0.28 \pm 0.10 *$ & $0.28 \pm 0.10 *$ & $0.64 \pm 0.09$ & $0.57 \pm 0.07$ \\
\hline \multirow{3}{*}{$\begin{array}{l}\text { Inflammatory } \\
\text { infiltration of } \\
\text { hepatic stroma }\end{array}$} & Lymphocytes & $0.50 \pm 0.00$ & $0.21 \pm 0.10 *$ & $0.50 \pm 0.10$ & $0.71 \pm 0.10$ \\
\cline { 2 - 6 } & Macrophages & 0 & 0 & 0 & $0.07 \pm 0.07$ \\
\cline { 2 - 6 } & General & $0.50 \pm 0.00$ & $0.21 \pm 0.10 *$ & $0.43 \pm 0.07$ & $0.71 \pm 0.10$ \\
\cline { 2 - 6 } & Penetration into the lobule & $0.21 \pm 0.10$ & $0.14 \pm 0.09$ & $0.43 \pm 0.17$ & $0.43 \pm 0.17$ \\
\hline
\end{tabular}

The test groups with adjuvant arthritis (AA) were treated from AA induction day: Group I with CBMDS preparation, Group II with a combination of CBMDS and methotrexate (MTX), Group III - with MTX. Group IV - AA control without treatment. Each parameter was scored on a 0 to 3 point scale, where 0 means the absence of changes, 0.5 - traces of changes, 1 - minimal changes, 2 - moderate changes, 3 - severe changes. * The differences are significant in comparison with the control AA group.

MTX alone significantly diminished IL-17 level by $70 \%(\mathrm{P}<0.02), 59.5 \%(\mathrm{P}<0.05)$ and $71.3 \%(\mathrm{P}<0.01)$ respectively in comparison with the control AA group (Fig. 3). Although a lower level of IL-1 $\beta$ was observed after the treatment with CBMDS and its combination with MTX, no significant differences in comparison with the control AA group were found. The herbal preparation diminished IL-1 $\beta$ concentration by $17.7 \%$ and CBMDS+MTX - by $14.5 \%$.

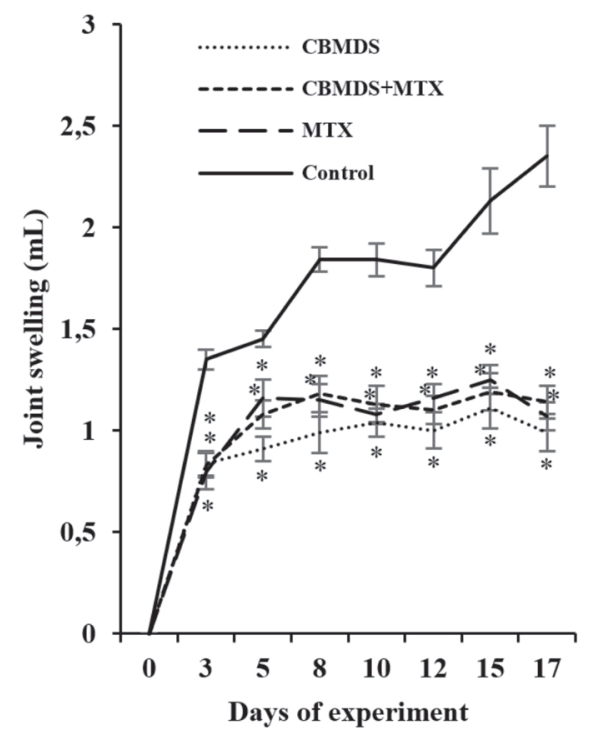

Fig. 1. Joint swelling in rats with adjuvant arthritis (AA) treated with CBMDS, its combination with methotrexate (MTX) and MTX alone. * The differences are significant in comparison with the control AA
Effect of preparations on lipid peroxidation and antioxidant activity. AA induced a rise in MDA level, reflecting serum lipid peroxidation. MDA decreased significantly, by $26.1 \%(\mathrm{P}<0.01)$ after the treatment of AA with CBMDS (Group I) and by $36 \%(\mathrm{P}<0.001)$ after combined treatment (Group II). CBMDS also enhanced CAT activity by $17.7 \%$ and CBMDS+MTX - by $14.5 \%$ (Fig. 4).
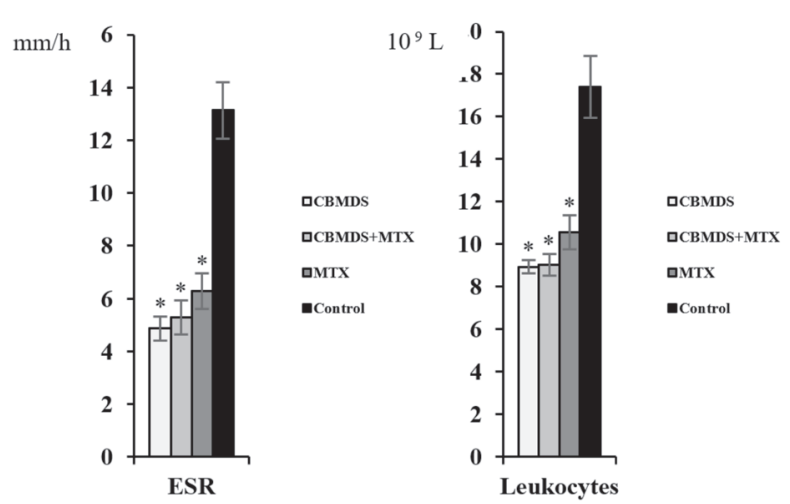

Fig. 2. Blood indices (erythrocyte sedimentation rate - ESR, leukocyte count) in rats with adjuvant arthritis (AA) treated with CBMDS, its combination with methotrexate (MTX) and MTX alone. * The differences are significant in comparison with the control AA group. 


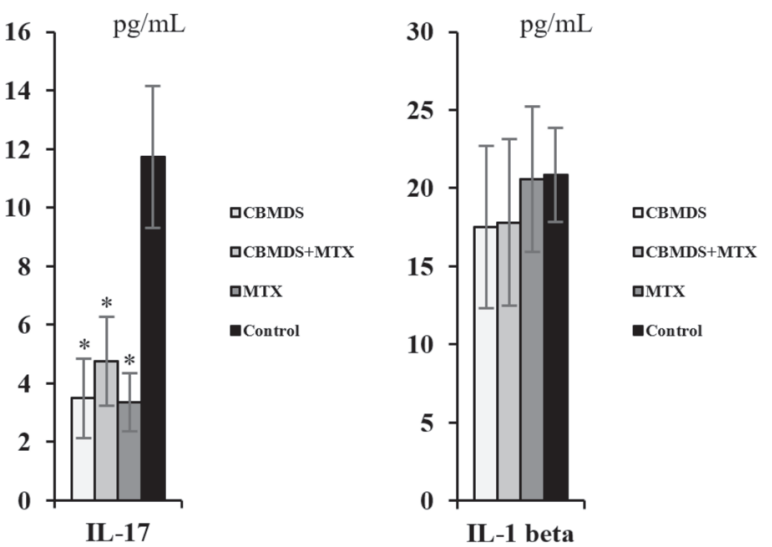

Fig. 3. Interleukin (IL-17 and IL-1 $\beta$ ) levels in rats with adjuvant arthritis (AA) treated with CBMDS, its combination with methotrexate (MTX) and MTX alone. * The differences are significant in comparison with the control AA group.

AOA increased by $74.3 \% \quad(\mathrm{P}<0.001)$ and $53.6 \%(\mathrm{P}<0.05)$ in both Groups I and II, treated with CBMDS and CBMDS+MTX combination, respectively. MTX alone only insignificantly diminished the MDA level by $16.6 \%$, and enhanced CAT activity and AOA by $7.9 \%$ and $2.5 \%$, respectively.
Histological changes in the liver. Treatment of AA with CBMDS and its combination with MTX significantly reduced $V$. centralis hypervolemia $(\mathrm{P}<0.05)$ compared to the control AA group (Table 2). The CBMDS+MTX also markedly decreased alteration of parenchymal hepatocytes (hyperchromatic and atypical nuclei, eventual small lipid droplets in cytoplasm, apoptotic fragments, and eventual tiny pericellular fibrosis; $\mathrm{P}<0.01)$. CBMDS+MTX diminished inflammatory infiltration of hepatic stroma with lymphocytes, and the general inflammatory reaction $(\mathrm{P}<0.01)$. So, the most beneficial effect on the liver was observed using the combined preparation CBMDS+MTX. The addition of the herbal preparation to MTX improved hepatic tissue changes caused by MTX toxicity.

Histological changes in the joint tissues. As shown in Table 3 and Fig. 5, the combined preparation CBMDS+MTX most strongly reduced changes in the soft periarticular tissues. It significantly decreased inflammatory infiltration with lymphocytes $(\mathrm{P}<0.02)$, leukocytes $(\mathrm{P}<0.002)$, and general inflammatory reaction $(\mathrm{P}<0.001)$.
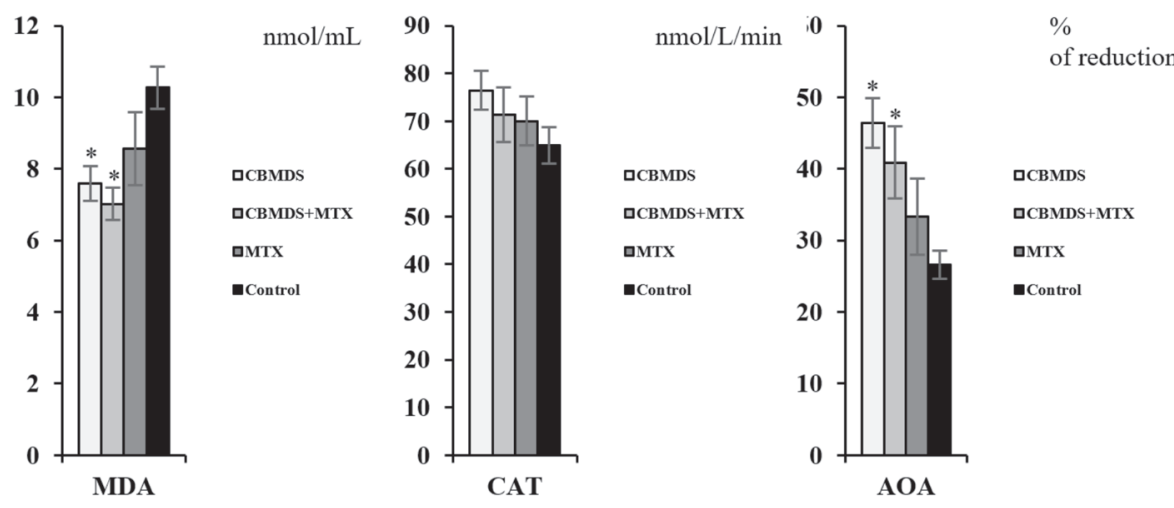

Fig. 4. Pro-/antioxidant indices (malondialdehyde - MDA, catalase - CAT, antioxidant activity - AOA) in blood serum of rats with adjuvant arthritis (AA) treated with preparation CBMDS, its combination with methotrexate

(MTX) and MTX alone. * The differences are significant in comparison with the control AA group 
R. Bradūnaite et al.: Complex natural substances ameliorate methotrexate effects in treatment of rat adjuvant arthritis

Table 3. Histological changes in joint tissues of rats with adjuvant arthritis treated with CBMDS preparation, its combination with MTX and MTX alone

\begin{tabular}{|c|c|c|c|c|c|c|}
\hline \multirow[b]{2}{*}{ Tissue } & \multirow{2}{*}{\multicolumn{2}{|c|}{ Index }} & \multicolumn{4}{|c|}{ Groups } \\
\hline & & & $\begin{array}{c}\mathrm{I} \\
\text { CBMDS }\end{array}$ & $\begin{array}{c}\text { II } \\
\text { CBMDS+MTX }\end{array}$ & $\begin{array}{c}\text { III } \\
\text { MTX }\end{array}$ & $\begin{array}{c}\text { IV } \\
\text { AA control }\end{array}$ \\
\hline \multirow{7}{*}{$\begin{array}{l}\text { Soft } \\
\text { periarticular } \\
\text { tissues }\end{array}$} & \multirow{4}{*}{$\begin{array}{l}\text { Inflammatory } \\
\text { infiltration }\end{array}$} & Lymphocytes & $1.75 \pm 0.21$ & $1.28 \pm 0.15 *$ & $1.92 \pm 0.20$ & $1.93 \pm 0.17$ \\
\hline & & Leukocytes & $0.17 \pm 0.10 *$ & $0.07 \pm 0.07 *$ & $0.25 \pm 0.11 *$ & $1.71 \pm 0.39$ \\
\hline & & Macrophages & $1.33 \pm 0.16$ & $0.93 \pm 0.17$ & $1.67 \pm 0.25$ & $1.36 \pm 0.14$ \\
\hline & & General & $1.83 \pm 0.16 *$ & $1.36 \pm 0.14 *$ & $2.08 \pm 0.20$ & $2.50 \pm 0.15$ \\
\hline & \multicolumn{2}{|l|}{ Edema } & $0.91 \pm 0.08 *$ & $0.50 \pm 0.00 *$ & $1.17 \pm 0.10 *$ & $2.29 \pm 0.10$ \\
\hline & \multicolumn{2}{|l|}{ Angiomatosis } & $0.83 \pm 0.10 *$ & $0.64 \pm 0.09 *$ & $1.25 \pm 0.11 *$ & $2.00 \pm 0.15$ \\
\hline & \multicolumn{2}{|c|}{$\gamma$-metachromasia } & $0.33 \pm 0.16 *$ & $0 *$ & $0 *$ & $1.36 \pm 0.18$ \\
\hline \multirow{8}{*}{ Synovium } & \multicolumn{2}{|l|}{ Proliferation } & $1.41 \pm 0.20 *$ & $0.93 \pm 0.17 *$ & $1.17 \pm 0.17 *$ & $2.21 \pm 0.15$ \\
\hline & \multicolumn{2}{|l|}{ Edema } & $0.83 \pm 0.16$ & $0.36 \pm 0.09 *$ & $0.58 \pm 0.08 *$ & $1.29 \pm 0.18$ \\
\hline & \multicolumn{2}{|c|}{$\gamma$-metachromasia } & $0.17 \pm 0.10$ & $0 *$ & $0.08 \pm 0.08$ & $0.36 \pm 0.14$ \\
\hline & \multirow{4}{*}{$\begin{array}{l}\text { Inflammatory } \\
\text { infiltration }\end{array}$} & Lymphocytes & $1.25 \pm 0.17 *$ & $0.43 \pm 0.20 *$ & $0.67 \pm 0.17 *$ & $1.79 \pm 0.15$ \\
\hline & & Leukocytes & $0.17 \pm 0.10 *$ & $0.14 \pm 0.09 *$ & $0.25 \pm 0.17 *$ & $1.43 \pm 0.33$ \\
\hline & & Macrophages & $0.91 \pm 0.27$ & $0.21 \pm 0.15 *$ & $0.33 \pm 0.21$ & $0.79 \pm 0.15$ \\
\hline & & General & $1.33 \pm 0.21 *$ & $0.50 \pm 0.19 *$ & $0.75 \pm 0.17 *$ & $2.00 \pm 0.15$ \\
\hline & \multicolumn{2}{|l|}{ Angiomatosis } & $0.75 \pm 0.11 *$ & $0.50 \pm 0.10 *$ & $0.67 \pm 0.10 *$ & $1.57 \pm 0.31$ \\
\hline \multirow{4}{*}{ Cartilage } & \multirow{2}{*}{ Alteration } & Erosion & $1.33 \pm 0.42$ & $0.64 \pm 0.23$ & $0.83 \pm 0.38$ & $1.14 \pm 0.40$ \\
\hline & & Usura & $0.50 \pm 0.18 *$ & $0.14 \pm 0.14 *$ & $0.17 \pm 0.10 *$ & $1.36 \pm 0.28$ \\
\hline & \multicolumn{2}{|l|}{ Pannus } & $0.25 \pm 0.17 *$ & $0.14 \pm 0.14 *$ & $0.17 \pm 0.10 *$ & $1.43 \pm 0.27$ \\
\hline & \multicolumn{2}{|c|}{ Thinning of cartilage } & $0.08 \pm 0.08 *$ & $0.07 \pm 0.07 *$ & $0.08 \pm 0.08 *$ & $0.71 \pm 0.18$ \\
\hline
\end{tabular}

Each parameter was scored on a 0 to 3 point scale, where 0 means the absence of changes, 0.5 - traces of changes, 1 - minimal changes, 2 - moderate changes, 3 - severe changes. * The differences are significant in comparison with the control AA group.
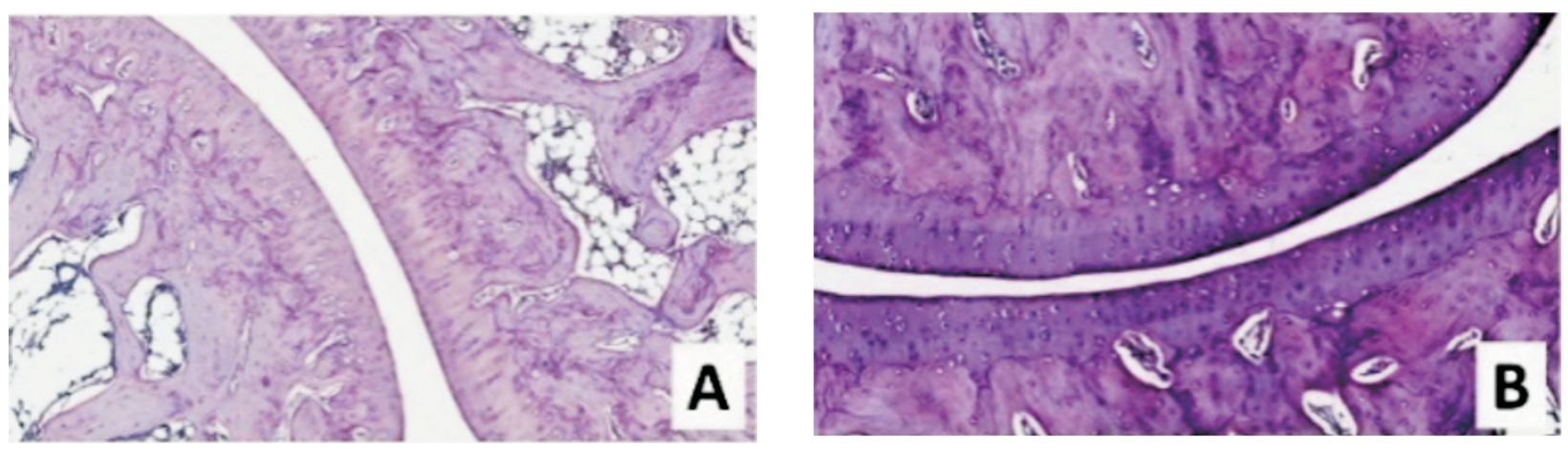

Figs. $5 \mathrm{~A}$ and $5 \mathrm{~B}$. Histological image of the joints in rats with adjuvant arthritis (AA) after treatment with preparation CBMDS, its combination with methotrexate (MTX) and MTX alone. A - CBMDS (160 mg/kg daily except weekends): smooth articular surface with mild hypocellularity, mild bone resorption, irregular tide mark. B CBMDS+MTX (2 mg/kg once a week): normal joint cartilage. 

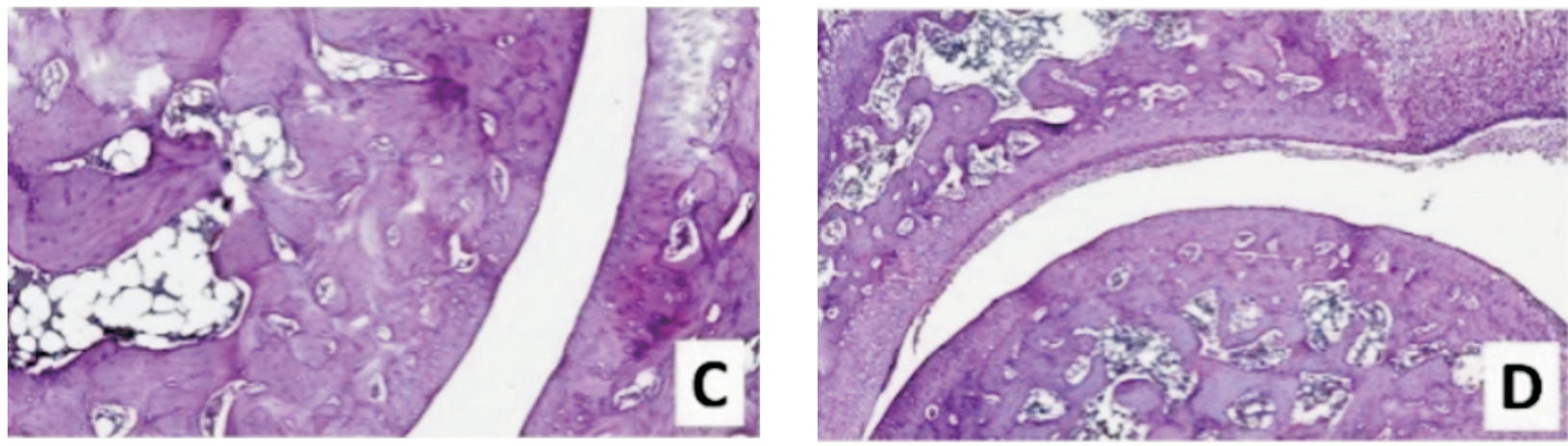

Figs. $5 \mathrm{C}$ and $5 \mathrm{D}$. Histological image of the joints in rats with adjuvant arthritis (AA) after treatment with preparation CBMDS, its combination with methotrexate (MTX) and MTX alone. C - MTX (2 mg/kg once a week):

cartilage hypocellularity, superficial clefts, destroyed tide mark, mild bone resorption. D - AA control without treatment: pannus, clefts to transitional zone, destroyed tide mark, moderate bone resorption. Original magnification $100 \mathrm{x}$, stained with hematoxylin and eosin (H\&E).

Tissue infiltration with macrophages was near to significant $(t=1.95)$ compared to the changes observed in the control AA group. MTX alone suppressed only infiltration with leukocytes $(\mathrm{P}<0.01)$, CBMDS - infiltration with leukocytes $(\mathrm{P}<0.01)$ and general inflammatory reaction $(\mathrm{P}<0.01)$. Notable suppression of edema $(\mathrm{P}<0.0001)$, angiomatosis $(\mathrm{P}<0.001 ; \mathrm{P}<0.002)$ and $\gamma$-metachromasia $(\mathrm{P}<0.002-0.001)$ were found in all treated groups.

Synovium proliferation was significantly $(\mathrm{P}<0.01-0.001)$ reduced in all treated groups, however, significant suppression of edema was only observed in Groups II and III treated with CBMDS+MTX $(\mathrm{P}<0.001)$ and MTX $(\mathrm{P}<0.01)$, respectively. Suppression of edema was only found to be close to significant $(\mathrm{t}=1.91)$ by applying a single CBMDS mixture for the treatment of AA. No signs of $\gamma$-metachromasia were observed in Group II ( $<0.05$ compared to the control AA group). CBMDS+MTX also significantly suppressed inflammatory infiltration with macrophages $(\mathrm{P}<0.02)$. A significant decrease in infiltration with lymphocytes $(\mathrm{P}<0.05-0.001)$, and leukocytes $(\mathrm{P}<0.01)$, a diminished general inflammatory reaction $(\mathrm{P}<0.05-0.001)$, and less angiomatosis $(\mathrm{P}<0.05-0.01)$ in the synovium were observed after treatment with the all preparations.

Studies of cartilage erosions showed no significant differences between the control AA group and the treated groups. Meanwhile, the usurae were found markedly suppressed in all the treated groups $(\mathrm{P}<0.05-0.002)$ (Table 3$)$.

All preparations significantly inhibited the formation of pannus $(\mathrm{P}<0.01-0.001)$. Decreased thinning of cartilage was observed using all protocols of treatment $(\mathrm{P}<0.01$, Table 3$)$.

\section{Discussion}

On the basis of studies by many researchers who have intensively investigated the biologically active substances of various plants and tried to apply them in the treatment of inflammatory processes and RA (JIANG et al., 2010; GANESAN et al., 2016), and also from our experience over the past years (AKRAMAS et al., 2017; AKRAMAS et al., 2019), we investigated for the first time a combined preparation of CBMDS alone or in combination with MTX on rats with AA, and compared their anti-inflammatory and antioxidant effects with MTX alone, which is widely used in the treatment of RA.

MTX alone or in combination with other medications is one of the most effective diseasemodifying antirheumatic drugs (DMARDs). Despite the well-known inflammation-reducing benefits of MTX, the use of this drug is associated with toxic effects (CHATZIDIONYSIOU and SFIKAKIS, 2019; FRIEDMAN and CRONSTEIN, 2019). $8-19 \%$ of patients discontinue MTX treatment due to adverse effects, such as gastrointestinal, hepatic, renal, pulmonary, and hematological disturbances, 
or even damage to the central nervous system (VARATHARAJAN et al., 2009; MAHMOUD et al., 2017). Other authors state that $26 \%$ of patients refuse MTX treatment due to poor response, high toxicity, or both (CHATZIDIONYSIOU and SFIKAKIS, 2019). MTX hepatotoxicity was demonstrated in our study, and these findings are in line with reports by other authors, showing damage of liver tissue following MTX therapy (BANJI et al., 2011; HE et al., 2019). An alternative solution is to combine MTX with other medications or natural products with anti-inflammatory and antioxidant properties, in order to eliminate or reduce MTX toxicity (BANJI et al., 2011; ZUO et al., 2018; ISMAIL et al., 2018; HE et al., 2019). On the basis of histological liver findings, we confirmed that there was less alteration of the hepatic parenchyma and fewer changes to the stroma in Group I (CBMDS) and particularly Group II (CBMDS+MTX) as compared to Group III (MTX) and the control AA group. The lowest scores of changes to the liver tissues were observed in the group of animals treated with CBMDS+MTX, which showed that the CBMDS preparation can inhibit MTX-induced hepatotoxicity. This effectmightbemostlyassociated with the silymarin in the investigated preparation. Silymarin can neutralize free radicals, suppress lipid peroxidation and lymphocyte proliferation, and improve liver function (HUSSAIN et al., 2009; POLYAK et al., 2010; ASHKAVAND et al., 2012; GHARAGOZLOO et al., 2013; FEDERICO et al., 2017; BARADARAN et al., 2019). The beneficial effect on the liver of other compounds in CBMDS also cannot be ruled out (BANJI et al., 2011).

In our trial, the combination of CBMDS with MTX for AA management significantly reduced joint swelling by $51.5 \% \quad(\mathrm{P}<0.0001)$. Although the reduction of joint swelling in the MTX group (54.6\%, $\mathrm{P}<0.0001)$ appeared to be slightly higher in comparison with the control group than in the CBMDS+MTX group, it should be noted that difference between the CBMDS+MTX and MTX groups is small and insignificant. Changes in joint tissues, confirmed by the histological examination, showed that the combination of CBMDS with MTX showed the best effect on the joints, with the smallest changes observed in soft joint tissue, synovium and cartilage. Also, there were no significant differences in terms of decreased leukocyte count between the treated groups, although CBMDS and CBMDS+MTX diminished leukocytosis to a higher degree. The greater reduction of leukocyte count in the CBMDS and CBMDS+MTX groups shows the positive anti-inflammatory effect of the test preparation. In addition, the course of arthritis in individual animals may not be completely identical. Apparently, this is what caused these small and insignificant differences between the treated groups.

The results obtained are not surprising, because the CBMDS preparation consists of dry extracts from turmeric, Boswellia, MSM, Devil's Claw, and silymarin. All the extracts in this mixture exert anti-inflammatory properties, and are suggested for the additional treatment of inflammatory arthritic processes (SHEHZAD et al., 2013; ROY et al., 2019; KARABAY et al., 2014; MENGHINI et al., 2019; AVATO and ARGENTIERI, 2019; POLYAK et al., 2013). In addition, the antiinflammatory activity of some of them, such as curcumin, seems to be comparable to steroid and non-steroid medications, such as indomethacin and phenylbutazone (MENON and SUDHEER, 2007).

The positive effects on the joints are apparently related to MSM and Devil's claw, which are included in the CBMDS. Preparation MSM has a beneficial effect on OA chondrocyte metabolism, probably due to the modulation of the NF-kB pathway (CHELESCHI et al., 2018), and is considered to be a source of sulfur for the production of sulfurcontaining amino acids, because sulfur is needed for the formation of connective tissue and in maintaining its function (PARCELL, 2002). Devil's claw extract not only inhibits the inflammatory process and cartilage degeneration in the joints, but also greatly improves blood circulation in the synovium, hence ensuring joint nutrition and toxin elimination (VLACHOJANNIS et al., 2008; WACHSMUTH et al., 2011).

The data from our research confirm and supplement the work of other authors on individual components of CBMDS, or some combinations, in which anti-arthritic, antioxidant and immunosuppressive effects were observed in animal models of arthritis (SCHAFFER et al., 2013; 
R. Bradūnaite et al.: Complex natural substances ameliorate methotrexate effects in treatment of rat adjuvant arthritis

HENROTIN and MOBASHERI, 2018; UCUNCU et al., 2015; KHAYYAL et al., 2018; MESHKIBAF et al., 2019; WANG et al., 2019; ESCOBEDOMARTÍNEZ et al., 2019).

The important mediators in the pathogenesis of RA are pro-inflammatory cytokines, such as IL-1 $\beta$, IL-17, TNF- $\alpha$, and IL-6 (MATEEN et al., 2016; ABOREHAB et al., 2017; WU et al., 2018). Elevated levels of TNF- $\alpha$ and IL-1 $\beta$ in damaged tissues, and IL-1 $\beta$ in serum were also observed in animals with arthritis (KUNCHA et al., 2013; ISMAIL et al., 2018). The T-cell product IL-17 plays a marked role as a mediator in RA pathogenesis. It stimulates inflammation by enhancing the production of IL-1 $\beta$, TNF- $\alpha$ and IL-6 (ZHANG et al., 2013; SHI et al., 2015). Its levels significantly increase in rats with AA compared with healthy animals, as has been demonstrated in our studies (AKRAMAS et al., 2017). A marked decrease in IL-17 by $59.5 \%$ and IL- $1 \beta$ by $14.5 \%$ in blood serum was found using CBMDS+MTX in our study. The fact that the levels of cytokines, such as IL-1 $\beta$ and IL-17, decrease after treatment with CBMDS and its combination with MTX, indicates the positive effect of these agents on the course of the pathological process.

No adverse animal behavior, clinical or physiological symptoms were observed during the treatment with the investigated products, which indicates their non-toxicity in vivo. In our study, the control AA group showed marked leukocytosis (which is a sign of AA). The treatment improved blood parameters. The significant decrease in ESR and leukocyte count in the treated groups, as compared with the control AA group, indicates the positive effect of tested agents.

Thus, the treatment with CBMDS and CBMDS+MTX did not show liver toxicity, but improved blood indices, and exhibited immunomodulatory effects by reducing the levels of pro-inflammatory cytokines, such as IL-17.

Excessive production of free radicals in arthritic animals and RA patients is associated with a stimulated pro-oxidant system and a deficient antioxidative defense system, leading to oxidative stress and lipid peroxidation. It causes not only synovium damage, but also injures other internal organs (HARUNA et al., 2007; COMAR et al., 2013). Antioxidant enzymes present in biological systems can protect the tissues from oxidative damage. The antioxidant, anti-inflammatory, antiproliferative and immunomodulatory effects of separate compounds in the CBMDS preparation have been described by other authors (POLYAK et al., 2013; ZANG et al., 2013; VAN DER MERWE and BLOOMER, 2016; CHELESCHI et al., 2018). Our trials have shown that the activity of AOA and CAT is lower in animals with AA, which is apparently associated with increased free radical production. The reduced activity of antioxidant enzymes correlates with the increased peroxidation of lipids, measured as the amount of MDA. It is well known that MDA is the end product of lipid peroxidation, and therefore its content can be used to evaluate lipid peroxidation (HUANG et al., 2012). Effective scavengers of reactive oxygen species are curcumin (MENON and SUDHEER, 2007; ESCOBEDO-MARTÍNEZ et al., 2019), Boswellia (UMAR et al., 2014), MSM (EZAKI et al., 2013; LUBIS et al., 2017), and Devil's claw (SCHAFFER et al., 2013). Our data from biochemical evaluation showed that MDA levels were significantly lower in the treated groups and the activity of AOA and CAT was higher than in the AA group without treatment. The increase in AOA in the CBMDS group was most pronounced, which is not surprising, as the compounds included in CBMDS have antioxidant activity. MTX, although effective in ameliorating the progress of AA, induces hepatic changes. As opposed to MTX, CBMDS and its combination with MTX protected the livers of AA rats, and downregulated oxidative stress by decreasing the MDA level and increasing AOA.

CBMDS+MTX showed the most beneficial effect on the liver in our study. This indicates that the preparation has a hepatoprotective effect, as was also observed by some other authors using curcumin, silymarin, and flavonoids together with MTX (BANJI et al., 2011; BARADARAN et al., 2019; HE et al., 2019).

In summary, it can be concluded that CBMDS and its combination with MTX could be useful as an alternative for reducing the side-effects of MTX in the treatment of adjuvant arthritis. Since the tested 
R. Bradūnaite et al.: Complex natural substances ameliorate methotrexate effects in treatment of rat adjuvant arthritis

CBMDS preparation showed anti-inflammatory, antioxidant and immunosuppressive activity in the treatment of experimental arthritis, it could also probably serve as a preventive or therapeutic agent for other autoimmune diseases. Experiments with larger numbers of animals, and other autoimmune disease models are needed, in order to prove its efficacy. The combination of natural substances such as CBMDS with conventional DMARDs such as MTX could be an alternative or complementary medicine therapy for RA in the future.

\section{References}

ABOREHAB, N. M., M. H. EL BISHBISHY, A. REFALY, N. E. WALY (2017): A putative chondroprotective role for IL-1 $\beta$ and MPO in herbal treatment of experimental osteoarthritis. BMC Complement. Altern. Med. 17, 495.

DOI: 10.1186/s12906-017-2002-y

AKRAMAS, L., L. LEONAVIČIENĖ, A. VASILIAUSKAS, R. BRADŪNAITÉ, D. VAITKIENĖ, D. ZABULYTÉ, T. NORMANTIENĖ, I. JONAUSKIENE் (2015): Antiinflammatory and anti-oxidative effect of herbal preparation EM 1201 in adjuvant arthritic rats. Medicina 51, 368-377. DOI: 10.1016/j.medici.2015.11.002

AKRAMAS, L, L. LEONAVICIENE, R. BRADUNAITE, A. VASILIAUSKAS, I. DUMALAKIENE, D. ZABULYTE, T. NORMANTIENE, I. JONAUSKIENE, D. VAITKIENE (2017): Antiinflammatory effect of herbal preparations on adjuvant arthritis in rats. Turk. J. Vet. Anim. Sci. 41, 748-756. DOI: $10.3906 /$ vet-1704-16

AKRAMAS, L., L. LEONAVIČIENĖ, R. BRADŪNAITĖ, D. VAITKIENĖ, V. VASILIAUSKAS, I. DUMALAKIENÉ, D. ZABULYTĖ, T. NORMANTIENĖ, I. JONAUSKIENE் (2019): Methylsulfonylmethane alone or in combination with thiocolchicoside modulate autoimmune disease in rats with adjuvant arthritis. J. Hellenic Vet. Med. Soc. 70, 15611572 .

DOI: $10.12681 /$ jhvms.20862

AMMON, H. P. (2016): Boswellic acids and their role in chronic inflammatory diseases. Adv. Exp. Med. Biol. 928, 291-327.

DOI: $10.1007 / 978-3-319-41334-1 \_13$

ANDERSEN, M. L., E. H. SANTOS, M. L. SEABRA, A. A. DA SILVA, S. TUFIK (2004): Evaluation of acute and chronic treatments with Harpagophytum procumbens on Freund's adjuvant-induced arthritis in rats. J. Ethnopharmacol. 91, 325-330.

DOI: $10.1016 /$ j.jep.2004.01.003

ASHKAVAND, Z., H. MALEKINEJAD, A. AMNIATTALAB, A. REZAEI-GOLMISHEH, B. S. VISHWANATH (2012): Silymarin potentiates the anti-inflammatory effects of
Celecoxib on chemically induced osteoarthritis in rats. Phytomedicine 19, 1200-1205.

DOI: $10.1016 /$ j.phymed.2012.07.008

AVATO, P., M. P. ARGENTIERI (2019): Quality assessment of commercial spagyric tinctures of Harpagophytum procumbens and their antioxidant properties. Molecules 24, 2251.

DOI: $10.3390 /$ molecules24122251

AXMANN, S., K. HUMMEL, K. NÖBAUER, E. RAZZAZI-FAZELI, K. ZITTERL-EGLSEER (2018): Pharmacokinetics of harpagoside in horses after intragastric administration of a Devil's claw (Harpagophytum procumbens) extract. J. Vet. Pharmacol. Ther. 42, 37-44.

DOI: $10.1111 /$ jvp.12716

BANJI, D., J. PINNAPAREDDY, O. J. BANJI, A. SAIDULU, M. S. HAYATH (2011): Synergistic activity of curcumin with methotrexate in ameliorating Freund's complete adjuvant induced arthritis with reduced hepatotoxicity in experimental animals. Eur. J. Pharmacol. 668, 293-298.

DOI: 10.1016/j.ejphar.2011.06.006

BARADARAN, A., F. SAMADI, S. S. RAMEZANPOUR, S. YOUSEFDOUST (2019): Hepatoprotective effects of silymarin on CCl4-induced hepatic damage in broiler chickens model. Toxicol. Rep. 6, 788-794.

DOI: 10.1016/j.toxrep.2019.07.011

BRADŪNAITĖ, R., L. LEONAVIČIENĖ, A. VENALIS, D. VAITKIENÉ, V. ASTRAUSKAS (2001): Azathioprine in combined therapy. Experimental treatment of autoimmune process. Acta Med. Litu. 8, 105-114.

BUTAWAN, M., R. L. BENJAMIN, R. J. BLOOMER (2017): Methylsulfonylmethane: applications and safety of a novel dietary supplement. Nutrients 9, 290.

DOI: $10.3390 /$ nu9030290

CHATZIDIONYSIOU, K., P. P. SFIKAKIS (2019): Low rates of remission with methotrexate monotherapy in rheumatoid arthritis: review of randomised controlled trials could point towards a paradigm shift. RMD Open 5, e000993.

DOI: 10.1136/rmdopen-2019-000993

CHELESCHI, S., A. FIORAVANTI, A. DE PALMA, C. CORALLO, D. FRANCI, N. VOLPI, G. BEDOGNI, S. GIANNOTTI, N. GIORDANO (2018): Methylsulfonylmethane and mobilee prevent negative effect of IL-1 $\beta$ in human chondrocyte cultures via NF- $\kappa B$ signaling pathway. Int. Immunopharmacol. 65, 129-139.

DOI: 10.1016/j.intimp.2018.10.004

COMAR, J. F., A. BABETO DE SÁ-NAKANISHI, A. L. DE OLIVEIRA, M. MARQUES NOGUEIRA WENDT, C. A. BERSANI AMADO, E. L. ISHII IWAMOTO, R. M. PERALTA, A. BRACHT (2013): Oxidative state of the liver of rats with adjuvant-induced arthritis. Free Radic. Biol. Med. 58, 144-53.

DOI: 10.1016/j.freeradbiomed.2012.12.003 
R. Bradūnaite et al.: Complex natural substances ameliorate methotrexate effects in treatment of rat adjuvant arthritis

DEBBI, E. M., G. AGAR, G. FICHMAN, Y. B. ZIV, R. KARDOSH, N. HALPERIN, A. ELBAZ, Y. BEER, R. DEBI (2011): Efficacy of methylsulfonylmethane supplementation on osteoarthritis of the knee: a randomized controlled study. BMC Complement. Altern. Med. 11, 50. DOI: $10.1186 / 1472-6882-11-50$

DUPUIS, M. L., F. CONTI, A. MASELLI, M. T. PAGANO, A. RUGGIERI, S. ANTICOLI, A. FRAGALE, L. GABRIELE, M. C. GAGLIARDI, M. SANCHEZ, F. CECCARELLI, C. ALESSANDRI, G. VALESINI, E. ORTONA, M. PIERDOMINICI (2018): The natural agonist of estrogen receptor $\beta$ silibinin plays an immunosuppressive role representing a potential therapeutic tool in rheumatoid arthritis. Front. Immunol. 9, 1903.

DOI: 10.3389/fimmu.2018.01903

ELSAYED ELGARAWANY, G., A.G. ABDOU, D. MAHER TAIE, S.M. MOTAWEA (2019): Hepatoprotective effect of artichoke leaf extracts in comparison with silymarin on acetaminophen-induced hepatotoxicity in mice.J. Immunoassay Immunochem 18, 1-13.

DOI: 10.1080/15321819.2019.1692029.

ESCOBEDO-MARTÍNEZ, C., S. L. GUZMÁN-GUTIÉRREZ, M. I. CARRILLO-LÓPEZ, M. A. DEVEZE-ÁLVAREZ, A. TRUJILlO-VALDIVIA, W. MEZA-MORALES, R. G. ENRÍQUEZ (2019): Diacetylcurcumin: its potential antiarthritic effect on a Freund's complete adjuvantinduced murine model. Molecules 24, 2643.

DOI: $10.3390 /$ molecules24142643

EZAKI, J., M. HASHIMOTO, Y. HOSOKAWA, Y. ISHIMI (2013): Assessment of safety and efficacy of methylsulfonylmethane on bone and knee joints in osteoarthritis animal model. J. Bone Miner. Metab. 31, 16-25. DOI: $10.1007 / \mathrm{s} 00774-012-0378-9$

FEDERICO, A., M. DALliO, C. LOGUERCIO (2017): Silymarin/silybin and chronic liver disease: a marriage of many years. Molecules 22, 191.

DOI: $10.3390 /$ molecules22020191

FRIEDMAN, B., B. CRONSTEIN (2019): Methotrexate mechanism in treatment of rheumatoid arthritis. Joint Bone Spine 86, 301-307.

DOI: 10.1016/j.jbspin.2018.07.004

GALAKTIONOVA, L. P., A. V. MOLCHANOV, S. A. EL'CHANINOVA, B. I. VARSHAVSKIII (1998): Lipid peroxidation in patients with gastric and duodenal peptic ulcers. Klin. Lab. Diagn. 6, 10-14 (in Russian).

GANESAN, R., H. M. DOSS, M. RASOOL (2016): Majoon ushba a polyherbal compound ameliorates rheumatoid arthritis via regulating inflammatory and bone remodeling markers in rats. Cytokine 77, 115-126.

DOI: $10.1016 /$ j.cyto.2015.11.002

GAVRILOV, V. B., A. R. GAVRILOVA, L. M. MAZHUL (1987): Methods of determining lipid peroxidation products in the serum using a thiobarbituric acid test. Vopr. Med. Khim. 33, 118-122 (in Russian).
GHARAGOZLOO, M., S. JAFARI, N. ESMAEIL, B. BAGHERPOUR, E. N. JAVID, A. REZAEI (2013): Immunosuppressive effect of silymarin on MAPK signaling pathway: the impact on $\mathrm{T}$ cell proliferation and cytokine production. Basic Clin. Pharmacol. Toxicol. 113, 209-214. DOI: $10.1111 /$ bcpt. 12088

GRABS, V., D. C. NIEMAN, B. HALLER, M. HALLE, J. SCHERR (2014): The effect of oral hydrolytic enzymes and flavonoids on inflammatory markers and coagulation after marathon running: study protocol for randomized, double-blind, placebo-controlled trial. BMC Sports Sci. Med. Rehabil. 6, 8.

DOI: $10.1186 / 2052-1847-6-8$

GREMESE, E., S. ALIVERNINI, B. TOLUSSO, M. P. ZEIDLER, G. FERRACCIOLI (2019): JAK inhibition by methotrexate (and csDMARDs) may explain clinical efficacy as monotherapy and combination therapy. J. Leukoc. Biol. 106, 1063-1068.

DOI: 10.1002/JLB.5RU0519-145R

HARUNA, Y., Y. MORITA, T. YADA, M. SATOH, D. A. FOX, N. KASHIHARA (2007): Fluvastatin reverses endothelial dysfunction and increased vascular oxidative stress in rat adjuvant-induced arthritis. Arthritis Rheum. 56, 18271835.

DOI: $10.1002 /$ art.22632

HENROTIN, Y., A. MOBASHERI (2018): Natural products for promoting joint health and managing osteoarthritis. Curr. Rheumatol. Rep. 20, 72.

DOI: 10.1007/s11926-018-0782-9

HE, D., Z. LIU, M. WANG, Y. SHU, S. ZHAO, Z. SONG, H. LI, L. LIU, W. LIANG, W. LI, Z. CAO, C. LU, A. LU, Y. LIU (2019): Synergistic enhancement and hepatoprotective effect of combination of total phenolic extracts of Citrus aurantium L. and methotrexate for treatment of rheumatoid arthritis. Phytother. Res. 33, 1122-1133.

DOI: $10.1002 /$ ptr.6306

HUANG, J., M. ZHU, Y. TAO, S. WANG, J. CHEN, W. SUN, S. LI (2012): Therapeutic properties of quercetin on monosodium urate crystal-induced inflammation in rat. $\mathrm{J}$. Pharm. Pharmacol. 64, 1119-1127.

DOI: $10.1111 / j .2042-7158.2012 .01504 . x$

HUSSAIN, S. A., N. A. JASSIM, I. T. NUMAN, I. I. ALKHALIFA, T. A. ABDULLAH (2009): Anti-inflammatory activity of silymarin in patients with knee osteoarthritis. A comparative study with piroxicam and meloxicam. Saudi Med. J. 30, 98-103.

ISMAIL, M., H. HASAN, Y. EL-ORFALI, H. ISMAIL, G. KHAWAJA (2018): Anti-inflammatory, antioxidative, and hepatoprotective effects of trans- $\Delta$ 9-tetrahydrocannabinol/ sesame oil on adjuvant-induced arthritis in rats. Evid. Based Complement. Alternat. Med. 2018, 9365464.

DOI: 10.1155/2018/9365464

JIANG, J. B., J. D. QIU, L. H. YANG, J. P. HE, G. W. SMITH, H. Q. LI (2010): Therapeutic effects of astragalus 
R. Bradūnaitè et al.: Complex natural substances ameliorate methotrexate effects in treatment of rat adjuvant arthritis

polysaccharides on inflammation and synovial apoptosis in rats with adjuvant-induced arthritis. Int. J. Rheum. Dis. 13, 396-405

DOI: $10.1111 / \mathrm{j} .1756-185 \mathrm{X} .2010 .01555 . \mathrm{x}$

KANDEMIR, F. M., S. KUCUKLER, C. CAGLAYAN, C. GUR, A. A. BATIL, I. GÜLCIN (2017): Therapeutic effects of silymarin and naringin on methotrexate-induced nephrotoxicity in rats: Biochemical evaluation of antiinflammatory, antiapoptotic, and antiautophagic properties. J. Food Biochemistry. 1-4.

DOI: $10.1111 /$ jbc. 12398

KARABAY, A. Z., F. AKTAN, A. SUNGUROĞLU, Z. BUYUKBINGOL (2014): Methylsulfonylmethane modulates apoptosis of LPS/IFN- $\gamma$-activated RAW 264.7 macrophage-like cells by targeting p53, Bax, Bcl-2, cytochrome $\mathrm{c}$ and PARP proteins. Immunopharmacol. Immunotoxicol. 36, 379-389.

DOI: $10.3109 / 08923973.2014 .956752$

KHAYYAL, M. T., R. M. EL-HAZEK, W. A. EL-SABBAGH, J. FRANK, D. BEHNAM, M. ABDEL-TAWAB (2018): Micellar solubilisation enhances the antiinflammatory activities of curcumin and boswellic acids in rats with adjuvant-induced arthritis. Nutrition 54, 189-196.

DOI: 10.1016/j.nut.2018.03.055

KOROLIUK, M. A., L. I. IVANOVA, I. G. MAĬOROVA, V. E. TOKAREV (1988): A method of determining catalase activity. Lab. Delo 1, 16-19 (in Russian).

KUMAR, R., S. SINGH, A. K. SAKSENA, R. PAL, R. JAISWAL, R. KUMAR (2019): Effect of Boswellia serrata extract on acute inflammatory parameters and tumor necrosis factor- $\alpha$ in complete Freund's adjuvant-induced animal model of rheumatoid arthritis. Int. J. Appl. Basic Med. Res. 9, 100-106.

DOI: 10.4103/ijabmr.IJABMR $248 \quad 18$

KUNCHA, M., V. G. NAIDU, B. D. SAHU, S. G. GADAPALLI, R. SISTLA (2013): Curcumin potentiates the anti-arthritic effect of prednisolone in Freund's complete adjuvantinduced arthritic rats. J. Pharm. Pharmacol. 66, 133-144.

DOI: $10.1111 /$ jphp. 12156

LUBIS, A. M. T., C. SIAGIAN, E. WONGGOKUSUMA, A. F. MARSETYO, B. SETYOHADI (2017): Comparison of glucosamine-chondroitin sulfate with and without methylsulfonylmethane in grade I-II knee osteoarthritis: a double blind randomized controlled trial. Acta Med. Indones. 49, 105-111.

MAHMOUD, A. M., O. E. HUSSEIN, W. G. HOZAYEN, S. M. ABD EL-TWAB (2017): Methotrexate hepatotoxicity is associated with oxidative stress, and down-regulation of PPAR $\gamma$ and Nrf2: Protective effect of 18ß-Glycyrrhetinic acid. Chem. Biol. Interact. 270, 59-72.

DOI: 10.1016/j.cbi.2017.04.009

MAJEED, M., S. MAJEED, N. K. NARAYANAN, K. NAGABHUSHANAM (2019): A pilot, randomized, double-blind, placebo-controlled trial to assess the safety and efficacy of a novel Boswellia serrata extract in the management of osteoarthritis of the knee. Phytother. Res. $33,1457-1468$.

DOI: $10.1002 /$ ptr.6338

MARAÑÓN, G., B. MUÑOZ-ESCASSI, W. MANLEY, C. GARCÍA, P. CAYADO, M. S. DE LA MUELA, B. OLÁBARRI, R. LEÓN, E. VARA (2008): The effect of methyl sulphonyl methane supplementation on biomarkers of oxidative stress in sport horses following jumping exercise. Acta Vet. Scand. 50, 45.

DOI: 10.1186/1751-0147-50-45

MATEEN, S., A. ZAFAR, S. MOIN, A. Q. KHAN, S. ZUBAIR (2016): Understanding the role cytokines in the pathogenesis of rheumatoid arthritis. Clin. Chim. Acta 455, 161-171.

DOI: 10.1016/j.cca.2016.02.010

MENGHINI,L.,L.RECINELLA, S.LEONE,A.CHIAVAROLI, C. CICALA, L. BRUNETTI, S. VLADIMIR-KNEŽEVIĆ, G. ORLANDO, C. FERRANTE (2019): Devil's claw (Harpagophytum procumbens) and chronic inflammatory diseases: A concise overview on preclinical and clinical data. Phytother. Res. 33, 2152-2162.

DOI: $10.1002 /$ ptr.6395

MENON, V. P., A. R. SUDHEER (2007): Antioxidant and antiinflammatory properties of curcumin. Adv. Exp. Med. Biol. $595,105-125$.

DOI: 10.1007/978-0-387-46401-5_3

MESHKIBAF, M. H., M. MALEKNIA, S. NOROOZI (2019): Effect of curcumin on gene expression and protein level of methionine sulfoxide reductase A (MSRA), SOD, CAT and GPx in Freund's adjuvant inflammation-induced male rats. J. Inflamm. Res. 12, 241-249.

DOI: $10.2147 /$ JIR.S212577;

DOI: $10.1016 /$ j.jep.2012.08.013

PARCELL, S. (2002): Sulfur in human nutrition and applications in medicine. Altern. Med. Rev. 7, 22-44.

POLYAK, S. J., C. MORISHIMA, V. LOHMANN, S. PAL, D. Y. LEE, Y. LIU, T. N. GRAF, N. H. OBERLIES (2010): Identification of hepatoprotective flavonolignans from silymarin. Proc. Natl. Acad. Sci. USA 107, 5995-5999.

DOI: 10.1073/pnas.0914009107

POLYAK, S. J., P. FERENCI, J. M. PAWLOTSKY (2013): Hepatoprotective and antiviral functions of silymarin components in hepatitis C virus infection. Hepatology 57, 1262-1271.

DOI: $10.1002 /$ hep.26179

ROY, N. K., D. PARAMA, K. BANIK, D. BORDOLOI, A. K. DEVI,K.K.THAKUR,G.PADMAVATHI,M.SHAKIBAEI, L. FAN, G. SETHI, A. B. KUNNUMAKKARA (2019): An update on pharmacological potential of boswellic acids against chronic diseases. Int. J. Mol. Sci. 20, 4101.

DOI: 10.3390/ijms20174101 
R. Bradūnaite et al.: Complex natural substances ameliorate methotrexate effects in treatment of rat adjuvant arthritis

SCHAFFER, L. F., L. R. PEROZA, A. A. BOLIGON, M. L. ATHAYDE, S. H. ALVES, R. FACHINETO, C. WAGNER (2013): Harpagophytum procumbens prevents oxidative stress and loss of cell viability in vitro. Neurochem. Res. $38,2256-2267$.

DOI: $10.1007 / \mathrm{s} 11064-013-1133-\mathrm{x}$

SHAVANDI, M., A. MOINI, Y. SHAKIBA, A. MASHKORINIA, M. DEHGHANI, S. ASAR, A. KIANI (2017): Silymarin (Livergol ${ }^{\circledR}$ ) decreases disease activity score in patients with rheumatoid arthritis: a non-randomized single-arm clinical trial. Iran. J. Allergy Asthma Immunol. 16, 99-106.

SHEHZAD, A., G. REHMAN, Y. S. LEE (2013): Curcumin in inflammatory diseases. Biofactors 39, 69-77.

DOI: 10.1002/biof.1066

SHI, F., D. ZHOU, Z. JI, Z. XU, H. YANG (2015): Anti-arthritic activity of luteolin in Freund's complete adjuvant-induced arthritis in rats by suppressing P2X4 pathway. Chem. Biol. Interact. 226, 82-87.

DOI: $10.1016 /$ j.cbi.2014.10.031

TATY ANNA, K., M. R. ELVY SUHANA, S. DAS, O. FAIZAH, A. H. HAMZAINI (2011): Anti-inflammatory effect of Curcuma longa (turmeric) on collagen-induced arthritis: an anatomico-radiological study. Clin. Ter. 162, 201-207.

UCUNCU, Y., N. CELIK, C. OZTURK, M. TURKOGLU, N. CETIN, N. KOCKARA, E. SENER, C. DUNDAR, A. ARSLAN, H. DOGAN, N. KURT, H. SULEYMAN (2015): Chondroprotective effects of a new glucosamine combination in rats: Gene expression, biochemical and histopathological evaluation. Life Sci. 130, 31-37.

DOI: 10.1016/j.1fs.2015.03.012

UMAR, S., K. UMAR, A. H. SARWAR, A. KHAN, N. AHMAD, S. AHMAD, C. K. KATIYAR, S. A. HUSAIN, H. A. KHAN (2014): Boswellia serrata extract attenuates inflammatory mediators and oxidative stress in collagen induced arthritis. Phytomedicine 21, 847-856.

DOI: 10.1016/j.phymed.2014.02.001

VAN DER MERWE, M., R. J. BLOOMER (2016): The influence of methylsulfonylmethane on inflammationassociated cytokine release before and following strenuous exercise. J. Sports Med. 2016, 7498359.

DOI: $10.1155 / 2016 / 7498359$

VARATHARAJAN, N., I. G. LIM, A. ANANDACOOMARASAMY, R. RUSSO, K. BYTH, D. G. SPENCER, N. MANOLIOS, G. B. HOWE (2009): Methotrexate: long-term safety and efficacy in an Australian consultant rheumatology practice. Intern. Med. J. 39, 228-236.

DOI: 10.1111/j.1445-5994.2009.01800.x
VLACHOJANNIS, J., B. D. ROUFOGALIS, S. CHRUBASIK (2008): Systematic review on the safety of Harpagophytum preparations for osteoarthritic and low back pain. Phytother. Res. 22, 149-152.

DOI: $10.1002 /$ ptr.2314

WACHSMUTH, L., E. LINDHORST, S. WRUBEL, H. HADZIYSKI, M. HUDELMAIER, F. ECKSTEIN, S. CHRUBASIK (2011): Micro-morphometrical assessment of the effect of Harpagophytum procumbens extract on articular cartilage in rabbits with experimental osteoarthritis using magnetic resonance imaging. Phytother. Res. 25, 1133-1140.

DOI: $10.1002 /$ ptr.3410

WANG, Q., C. YE, S. SUN, R. LI, X. SHI, S. WANG, X. ZENG, N. KUANG, Y. LIU, Q. SHI, R. LIU (2019): Curcumin attenuates collagen-induced rat arthritis via antiinflammatory and apoptotic effects. Int. Immunopharmacol. 72, 292-300.

DOI: 10.1016/j.intimp.2019.04.027

WIANOWSKA, D., M. WIŚNIEWSKI (2015): Simplified procedure of silymarin extraction from Silybum marianum L. Gaertner. J. Chromatogr. Sci. 53, 366-372.

DOI: 10.1093/chromsci/bmu049

WU, D., B. HUA, Z. FANG, J. LIU, N. LIU, Y. MA (2018): Adiponectin exerts a potent anti-arthritic effect and insulin resistance in collagen-induced arthritic rats. Int. J. Rheumat. Dis. 21, 1496-1503.

DOI: $10.1111 / 1756-185 X .13141$

ZHANG, L., L. FENG, Q. JIA, J. XU, R. WANG, Z. WANG, Y. WU, Y. LI (2011): Effects of $\beta$-glucosidase hydrolyzed products of harpagide and harpagoside on cyclooxygenase-2 (COX-2) in vitro. Bioorg. Med. Chem. $19,4882-4886$.

DOI: $10.1016 /$ j.bmc.2011.06.069

ZHANG, Y., G. REN, M. GUO, X. YE, J. ZHAO, L. XU, J. QI, F. KAN, M. LIU, D. LI (2013): Synergistic effects of interleukin-1 $\beta$ and interleukin-17A antibodies on collageninduced arthritis mouse model. Int. Immunopharmacol. 15, 199-205.

DOI: 10.1016/j.intimp.2012.12.010

ZUO, J., Q. YIN, L. WANG, W. ZHANG, Y. FAN, Y. Y. ZHOU, Y. LI, G. D. WANG (2018): Mangosteen ethanol extract alleviated the severity of collagen-induced arthritis in rats and produced synergistic effects with methotrexate. Pharm. Biol. 56, 455-464.

DOI: $10.1080 / 13880209.2018 .1506939$ 
R. Bradūnaite et al.: Complex natural substances ameliorate methotrexate effects in treatment of rat adjuvant arthritis

Received: 28 February 2020

Accepted: 24 August 2020

BRADŪNAITÉ, R., L. LEONAVIČIENĖ, L. AKRAMAS, A. VASILIAUSKAS, I. DUMALAKIENE், R. VILIENE், I. JONAUSKIENE், Z. MACKIEWICZ, M. LEONAVIČIŪTE் - KLIMANTAVIČIENE்: Učinak mješavine biljnih ekstrakata i metotreksata na supresiju adjuvantnog artritisa u štakora. Vet. arhiv 91, 411425, 2021.

\section{SAŽETAK}

U ovom je radu procijenjena terapijska korist mješavine biljnih preparata pod imenom CBMDS, koja sadržava kurkumu (Curcuma longa), tamjanovo drvo (Boswellia serrata), metilsulfonilmetan, vražju kandžu (Harpagophytum procumbens) i silimarin. Biljni preparati su upotrijebljeni u kombinaciji s metotrekstom s ciljem supresije adjuvantnog artritisa u štakora i smanjenja oštećenja jetre uzrokovanog metotreksatom. Adjuvantni artritis izazvan je u 28 štakora pojedinačnom subplantarnom injekcijom mineralne uljne emulzije Freund's Complete Adjuvant $(0,1 \mathrm{~mL}) \mathrm{u}$ stražnju lijevu šapu. Životinje su podijeljene u četiri skupine (u svakoj po sedam jedinki). Skupina I primila je CBMDS, skupina II - CBMDS u kombinaciji s metotreksatom, a skupina III - metotreksat. Pokus je trajao od nultog do 17. dana (CBMDS je davan svaki dan, osim vikendom, u dozi od $160 \mathrm{mg} / \mathrm{kg}$, metotreksat u dozi od $2 \mathrm{mg} / \mathrm{kg}$ jedanput tjedno). Skupina IV bila je kontrolna skupina. Procijenjene su kliničke (tjelesna masa, opseg stražnje šape, sedimetacija eritrocita, broj leukocita), biokemijske (marker serumske aktivnosti prooksidansa i antioksidansa), imunološke (razine serumskog interleukina) i histološke promjene u zglobovima i jetri. CBMDS je znakovito ublažio artritis i smanjio oštećenje jetre, što je bilo očitije u skupini s metotreksatom. Kombinirana terapija također je znatno smanjila simptome artritisa i razine malondialdehida. Antioksidacijska aktivnost bila je znakovito veća u skupinama I i II. CBMDS u kombinaciji s metotreksatom imao je antiartritično djelovanje, smanjio je histološke promjene u zglobovima i minimizirao toksičnost metotreksata za jetru.

Ključne riječi: adjuvantni artritis; kompleks biljnih ekstrakata; metotreksat; antioksidacijska aktivnost 
